\section{DOWNY WOODPECKER SHOWS INVESTIGATIVE BEHAVIOUR TO ARTIFICIAL MOUSE}

ROBERT W. NERO, Manitoba Wildlife Branch, Box 14, 1495 St. James St., Winnipeg, Manitoba. R3H OW9

At noon on 23 January 1983, Herb Copland and I were trying to capture a Great Gray Owl we had found just off PTH 12, on the road to Menisino, in extreme southeastern Manitoba. It was a perfect day for looking for owls to band - heavily overcast, calm and mild.

Herb was on his knees on the edge of the road in readiness to net the owl if it came in to the artificial mouse that has proved to be so effective in bringing in owls close enough to catch. I was standing beside Herb, casting the lure across the road and reeling it in; the owl was some distance back from the road in a stand of aspen.

The "mouse" consists of a flat piece of wood approximately $4 \frac{1}{2}$ inches long and 2 inches wide, covered with artificial fur (from a fur hat), and has a piece of shoestring for a tail. Reeled in across the snow it somewhat resembles an oversized mouse. Responsive (and presumably hungry) Great Gray Owls have come from as far as 200 yards to pursue the lure close enough to be netted.

I had cast and retrieved the lure several times, with no response from the watching owl, when suddenly a female Downy Woodpecker flew in from behind us and swooped low over the moving lure, coming down within two feet of it, then continuing on across the road to perch on the trunk of an aspen tree where it proceeded to inch upwards in typical woodpecker fashion. The woodpecker had flown within a few feet of us; when it dipped down and swooped at the lure it was still no more

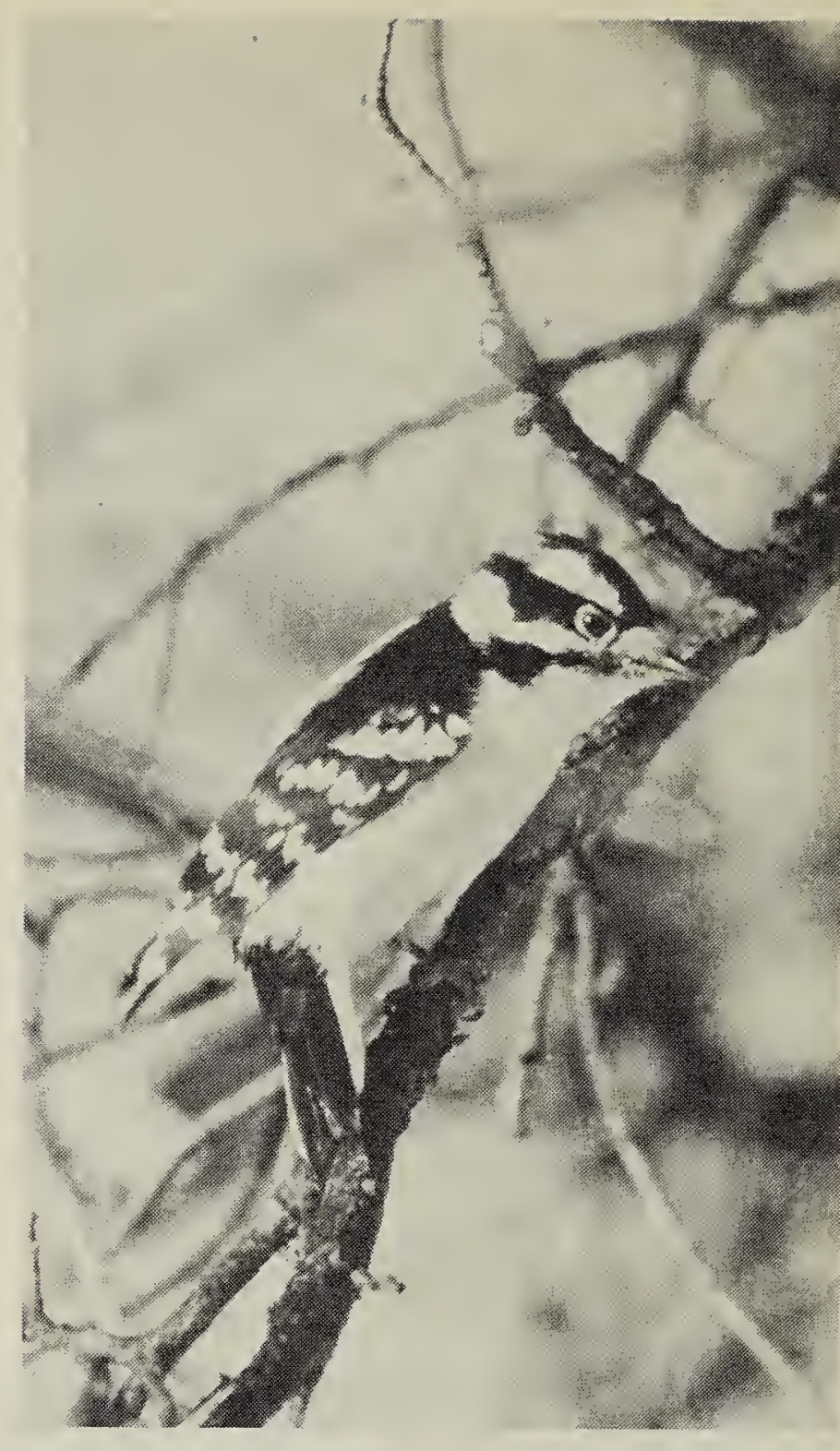

Downy Woodpecker.

Gary W. Seib

than six or eight feet away.

On the next cast across the road, shortly after I started to reel in the lure, the woodpecker again flew straight towards the lure, dropping down at it as if trying to harass it or get a better look. The woodpecker followed the lure briefly and then, as the lure was brought in and lifted up, flew away behind us.

Over many years and in many hundreds of casts made with this lure we have not witnessed any bird other than an owl (including Great Gray Owl, Barred Owl, Great Horned Owl, Snowy Owl, and Hawk Owl) show any interest in the lure. We were both astonished and mystified by the woodpecker's reaction to the lure. It was completely unexpected and we have no explanation to offer for this slight but peculiar observation. 